\title{
SORPTION OF INDAZIFLAM IN BRAZILIAN SOILS WITH DIFFERENT pH VALUES $^{1}$
}

\author{
VALDINEI ARAÚJO GONÇALVES ${ }^{2}$, LINO ROBERTO FERREIRA ${ }^{2}$, MATHEUS FERREIRA FRANÇA TEIXEIRA $^{2}$, \\ FRANCISCO CLÁUDIO LOPES DE FREITAS ${ }^{2}$, LEONARDO D'ANTONINO²*
}

\begin{abstract}
Pre-emergence herbicides, such as indaziflam, have agronomic efficiency when available in the soil solution, mainly in the superficial layer $(0-10 \mathrm{~cm})$, the region with the highest concentration of weed seed bank. However, information about the sorption of indaziflam in Brazilian soils still is scarce, since most studies available in the literature were conducted in soils of temperate regions. The objective of this study was to estimate the sorption of indaziflam using high-performance liquid chromatography (HPLC) and bioassay in a Latossolo Vermelho-Amarelo (Oxisol) and in a Cambissolo (Inceptisol), at $\mathrm{pH}$ values of 5.1 and 6.1. In the biossay, Sorghum bicolor was used as an indicator plant. Quantitative indaziflam data were obtained by HPLC, and the sorption and desorption coefficients were determined in the soils using Freundlich isotherms. Increasing the $\mathrm{pH}$ of the two soils from 5.1 to 6.1 resulted in reductions of $\mathrm{C}_{50}$ and sorption coefficient values. Desorption, a parameter estimated only by HPLC, showed an inverse behavior to that of sorption, that is, the lowest desorption was observed in the condition of highest sorption. It is concluded that the increase in $\mathrm{pH}$ of the studied soils reduces indaziflam sorption, influencing the recommendations of this herbicide, from both the agronomic and the environmental points of view. When the goal is to verify the presence or absence of indaziflam in the studied soils, the bioassay technique has satisfactory efficiency. Chromatographic assay is necessary when quantifying the concentration of this herbicide in the soil.
\end{abstract}

Keywords: Herbicide in soil. Environmental impact. Bioassay. HPLC.

\section{SORÇÃO DO INDAZIFLAM EM SOLOS DO BRASIL COM DIFERENTES VALORES DE pH}

RESUMO - Herbicidas aplicados em pré-emergência, como o indaziflam, têm eficiência agronômica quando disponíveis na solução do solo, principalmente na camada superficial $(0-10 \mathrm{~cm})$, região de maior concentração do banco de sementes das plantas daninhas. Contudo, as informações acerca da sorção do indaziflam em solos brasileiros ainda são escassas, pois a maioria dos estudos disponíveis na literatura foram conduzidos em solos de regiões temperadas. O objetivo desse estudo foi estimar a sorção do indaziflam, utilizando a técnica da cromatografia líquida de alta eficiência (CLAE) e do bioensaio em um Latossolo Vermelho-Amarelo e Cambissolo nos valores de pH 5,1 e 6,1. No ensaio biológico foi utilizado o Sorghum bicolor como planta indicadora. Os dados quantitativos do indaziflam foram obtidos por CLAE e os coeficientes de sorção e dessorção foram determinados em solos utilizando as isotermas de Freundlich. A elevação do valor de $\mathrm{pH}$ dos dois solos de 5,1 para 6,1, proporcionou diminuição da $\mathrm{C}_{50}$ e dos valores do coeficiente de sorção. A dessorção, parâmetro estimado apenas pela CLAE, apresentou comportamento inverso ao da sorção, ou seja, na condição de maior sorção foi observada a menor dessorção. A elevação do pH dos solos estudados diminui a sorção do indaziflam, influenciando as recomendações desse herbicida, tanto do ponto de vista agronômico quanto ambiental. Quando se pretende verificar a presença ou ausência do indaziflam no solo a técnica do bioensaio possui eficiência satisfatória. Na quantificação da concentração desse herbicida no solo é necessária à realização do ensaio cromatográfico.

Palavras-chave: Herbicida no solo. Impacto ambiental. Bioensaio. CLAE.

\footnotetext{
${ }^{*}$ Corresponding author

${ }^{1}$ Received for publication in $11 / 12 / 2019$; accepted in $01 / 22 / 2021$.

Paper extracted from the doctoral thesis of the first author.

${ }^{2}$ Department of Agronomy, Universidade Federal de Viçosa, MG, Brazil; valdinei.goncalves0109@gmail.com - ORCID: 0000-0001-95870452 lroberto@ufv.br - ORCID: 0000-0003-1227-9662, teixeiramff@gmail.com - 0000-0001-5773-3027, francisco.freitas@ufv.br ORCID: 0000-0003-1911-7201, leonardo@ufv.br-ORCID: 0000-0002-9542-365X.
} 


\section{INTRODUCTION}

The interference of weeds in agricultural crops has been one of the main critical points of the production process. Chemical control with herbicides has been the most used strategy in weed control due to lower dependence on labor and higher efficiency in the control with selectivity to crops (FAOSTAT, 2018; SILVA et al., 2013a).

When herbicides are applied in preemergence, it is essential that they remain for a certain period of time available in the soil solution, that is, their bioavailability, and the process that controls this bioavailability is called sorption (SILVA; VIVIAN; OLIVEIRA JR., 2013; KHAN; BROWN, 2017). Thus, it is necessary to know the interactions of herbicide molecules with the soil, so that they are used correctly, increasing agronomic efficiency and minimizing the risks of contamination of natural resources such as water and soil (CARLES; JOLY; JOLY, 2017; ALONSO et al., 2016; CALDERON et al., 2016).

The herbicide Indaziflam (N-[(1R,2S)-2,3dihydro-2,6-dimethyl-1H-inden-1-yl]-6-[(1R)-1fluoroethyl]-1,3,5-triazine-2,4-diamine), is registered in Brazil for use in pre-emergence of weeds in coffee, sugarcane, eucalyptus, pine, and some perennial fruit crops such as banana, cashew, citrus, coconut, palm, guava, apple, mango and grape (AGROFIT, 2020). Belonging to the alkylazine chemical class, it has as mechanism of action the inhibition of cell wall biosynthesis (JEFFRIES; GANON, 2016; BRABHAM et al., 2014; GUERRA et al., 2013). Inhibition probably occurs at some point in the crosslinking stage of cellulose microfibrils (JEFFRIES; GANON, 2016; KAAPRO; HALL, 2012). The main characteristics are: prolonged residual effect on weed control (BROSNAN et al., 2012) with persistence greater than 150 days, low solubility in water $\left(0.0028 \mathrm{~kg} \mathrm{~m}^{-3}\right.$ at $20{ }^{\circ} \mathrm{C}$ ) and $\mathrm{pKa}=3.5$ (U.S. EPA, 2010).

The sorption of indaziflam and its metabolites is influenced by soil properties (ALONSO et al., 2015). Studies on the sorption of this herbicide in Brazilian soils, which have predominance of $1: 1$ minerals, such as kaolinite, with low expansion capacity and $\mathrm{pH}$-dependent charges, are scarce. Most of the studies available in the literature were conducted in soils of temperate regions. These generally have characteristics such as expandable clay minerals $(2: 1)$ with larger specific surface area, such as montmorillonite and vermiculite (ALONSO et al., 2011; ALONSO et al., 2015; JHALA;
RAMIREZ; SINGH, 2012).

Studies with herbicides derived from weak acids, such as indaziflam, have shown that these compounds are more adsorbed to the soil in the presence of higher levels of organic matter (BARCELLOS JÚNIOR et al., 2020).

The study of herbicide sorption in the soil can be conducted using the technique of highperformance efficiency liquid chromatography (HPLC), which has great precision in qualitative and quantitative analyses. It can also be conducted using the bioassay, which consists of using plant species with high sensitivity to the herbicide of interest, which are called bioindicators (INOUE et al., 2007).

Chromatographic analyses require sophisticated laboratories and large amounts of solvents and other chemical reagents, which may make the use of this technique unfeasible. However, the advantage is the determination of the amount of herbicide that is free and active in the soil (SILVA et al., 2012). On the other hand, the detection by the bioassay stands out as a simpler and lower-cost process, since structures and equipment with high added value are not used, facilitating the execution of the work (MELO et al., 2010).

Thus, due to the lack of studies related to indaziflam sorption in Brazilian soils, the present study was conducted using the bioassay and highperformance liquid chromatography methods in two Brazilian soils, both at two $\mathrm{pH}$ values. Complementarily, the results obtained were compared in order to clarify the efficiency of the methods used.

\section{MATERIAL AND METHODS}

The experiments were carried out in a greenhouse and in the Herbicide in Soil Laboratory of the Federal University of Viçosa. Samples were collected at 0-20 cm depth in two soils with different characteristics, Latossolo Vermelho-Amarelo (LVA) (Oxisol), from the region of Viçosa-MG, and Cambissolo (CX) (Inceptisol), from the region of Santa Vitória-MG.

The samples were sieved through a 4-mm mesh and then divided into two subsamples. One sample was maintained with natural $\mathrm{pH}$ (5.1) and the other had the $\mathrm{pH}$ corrected to 6.1 , by means of acidity neutralization curve, using dolomitic limestone (RNV 80\%) and an incubation time of 30 days. Subsequently, the samples were characterized physically and chemically (Table 1). 
Table 1. Physical and chemical characterization of the soil samples used in the experiment.

\begin{tabular}{|c|c|c|c|c|c|c|c|c|c|c|c|c|c|}
\hline \multicolumn{14}{|c|}{ Physical Analysis } \\
\hline \multirow{2}{*}{ Soil } & \multicolumn{3}{|c|}{ Sand } & \multirow{2}{*}{\multicolumn{3}{|c|}{$\begin{array}{l}\text { Silt } \\
\left(\operatorname{dag~Kg^{-1}}\right)\end{array}$}} & \multirow{2}{*}{\multicolumn{4}{|c|}{ Clay }} & \multirow{2}{*}{\multicolumn{3}{|c|}{ Textural class }} \\
\hline & & & & & & & & & & & & & \\
\hline LVA - Viçosa, MG & \multicolumn{3}{|c|}{43.0} & \multicolumn{3}{|c|}{7.0} & & \multicolumn{2}{|c|}{50.0} & & \multicolumn{3}{|c|}{ Sandy clay } \\
\hline $\mathrm{CX}$ - Santa Vitória, $\mathrm{MG}$ & & 81.0 & & \multicolumn{3}{|c|}{4.0} & & \multicolumn{2}{|c|}{15.0} & & \multicolumn{3}{|c|}{ Loamy sand } \\
\hline \multicolumn{14}{|c|}{ Chemical Analysis } \\
\hline \multirow[t]{2}{*}{ Soil } & $\mathrm{pH}$ & $\mathrm{P}$ & $\mathrm{K}$ & $\mathrm{Ca}$ & $\mathrm{Mg}^{2+}$ & $\mathrm{Al}^{3+}$ & $\mathrm{H}+\mathrm{Al}$ & SB & $\mathrm{T}$ & $\mathrm{T}$ & $\mathrm{V}$ & $\mathrm{m}$ & $\mathrm{OM}$ \\
\hline & $\left(\mathrm{H}_{2} \mathrm{O}\right)$ & \multicolumn{2}{|c|}{$\left(\mathrm{mg} \mathrm{dm}{ }^{-3}\right)$} & \multicolumn{6}{|c|}{$\left(\mathrm{cmol}_{\mathrm{c}} \mathrm{dm}^{-3}\right)$} & & \multicolumn{2}{|c|}{$(\%)$} & $\left(\right.$ dag $\left.\mathrm{kg}^{-1}\right)$ \\
\hline $\begin{array}{l}\text { LVA - Viçosa, MG } \\
\text { Without liming }\end{array}$ & 5.1 & 2.2 & 33 & 3.4 & 0.1 & 0.00 & 5.45 & 3.58 & 3.58 & 9.03 & 40 & 0 & 3.47 \\
\hline $\begin{array}{c}\text { LVA - Viçosa, MG } \\
\text { With liming } \\
\end{array}$ & 6.1 & 2.9 & 41 & 4.7 & 0.1 & 0.00 & 3.30 & 4.90 & 4.90 & 8.20 & 60 & 0 & 3.47 \\
\hline $\begin{array}{c}\text { CX - Santa Vitória, MG } \\
\text { Without liming }\end{array}$ & 5.1 & 69.6 & 23 & 1.0 & 0.6 & 0.2 & 2.97 & 1.66 & 1.86 & 4.63 & 36 & 11 & 1.86 \\
\hline $\begin{array}{l}\mathrm{CX}-\text { Santa Vitória, MG } \\
\text { With liming }\end{array}$ & 6.1 & 71.9 & 27 & 2.7 & 1.0 & 0.0 & 1.30 & 3.70 & 3.70 & 5.20 & 56 & 12 & 1.86 \\
\hline
\end{tabular}

pH: water, $\mathrm{KCl}$ and $\mathrm{CaCl}_{2}-1: 2.5$ ratio. P-K: Extracted with Mehlich 1. Ca-Mg and Al: Extracted with 1 mol $\mathrm{L}^{-1} \mathrm{KCl}_{\mathrm{H}}+$ $\mathrm{Al}$ - Potential acidity: Extracted with $0.5 \mathrm{~mol} \mathrm{~L}^{-1}$ calcium acetate; $\mathrm{SB}$ - Sum of exchangeable bases; $\mathrm{t}$ - Effective cation exchange capability; $\mathrm{T}$ - Cation exchange capacity at $\mathrm{pH} 7.0 ; \mathrm{V}$ - Base saturation index; $\mathrm{m}$ - Aluminum saturation index; $\mathrm{OM}$ - Organic matter.

\section{Determination of sorption by the bioassay method}

The experiment was conducted in a greenhouse. Five substrates were used, which consisted of the two soils (LVA and CX) with two $\mathrm{pH}$ values (5.1 and 6.1) and an inert substrate (washed sand), which was used to construct the indaziflam dose-response curve. The experimental design used was completely randomized, with four replicates.

The inert substrate was obtained from the incubation of sand with $\mathrm{HCl}$ solution for $24 \mathrm{~h}$, followed by washing in running water and reincubation for more $24 \mathrm{~h}$ with $\mathrm{NaOH}$ solution, with a new washing using running water in abundance until reaching $\mathrm{pH} 7.0$, according to the methodology used by Braga et al. (2020).

The substrates were placed in pots with sealed bottoms, with capacity of $300 \mathrm{~cm}^{3}$. Then, the herbicide was applied at different doses, which were defined in preliminary tests, for each substrate: soil $(0 ; 1 ; 2 ; 4 ; 8 ; 16 ; 32 ; 64 ; 100 ; 200 \mathrm{~g}$ of indaziflam $\mathrm{ha}^{-1}$ - Commercial product Alion $^{\circledR}$ $\left.500 \mathrm{~g} \mathrm{~L}^{-1}\right)$ and inert substrate $(0 ; 0.06 ; 0.12 ; 0.25$; $0.50 ; \quad 1.00 ; \quad 2.00 ; \quad 3.00 ; \quad 5.00 ; \quad 10.00 \mathrm{~g}$ of indaziflam $\mathrm{ha}^{-1}$ ). Herbicide application was performed using a $\mathrm{CO}_{2}$-pressurized backpack sprayer, equipped with two TTI 110.02 nozzles, spaced by $0.5 \mathrm{~m}$, maintained at a pressure of $300 \mathrm{kPa}$, applying a volume corresponding to $150 \mathrm{~L}$ $\mathrm{ha}^{-1}$. During application, air temperature was $23.6{ }^{\circ} \mathrm{C}$, relative humidity was $69 \%$ and wind speed was $1.8 \mathrm{~km} \mathrm{~h}^{-1}$.

After application of indaziflam, the contents of each pot were put into plastic bags to homogenize the herbicide in the entire substrate volume. Then, each pot received three seeds of Sorghum bicolor, cultivar BRS 506, a species used as an indicator plant for the presence of indaziflam (BRAGA, 2017). Subsequently, the pots were kept in a greenhouse for 21 days, with irrigation and fertilization with nutritional complementation solution based on NPK and micronutrients (BRAGA et al., 2020)

At 21 days after sowing, the percentage of intoxication of sorghum plants was evaluated, assigning scores from 0 (emergence and normal development of the plant) to 100 (absence of germination or death of the plant) according to the scale of SBCPD (1995). Subsequently, the plants were cut close to the surface of the substrates and their root system was washed under running water. All harvested material was dried in a forced air circulation oven $\left(70 \pm 2{ }^{\circ} \mathrm{C}\right)$ for 48 hours. The values of total dry matter (DM) accumulation of the plants were transformed to percentage relative to the DM of the control (zero dose).

The results were interpreted using nonlinear regression, adopting the exponential model that best fitted to the behavior of the variables analyzed. Then, $C_{50}$ (indaziflam dose capable of causing $50 \%$ intoxication and $50 \%$ reduction in the total dry matter accumulation of the indicator plant) was determined in the soils and in the inert substrate. Then, the $C_{50}$ values obtained for each substrate and Equation 1 were used to determine the sorption rate (SR) of indaziflam in the soils (Equation 1) (SILVA et al., 2013b), in comparison to the response of the 
indicator species obtained in sand.

Equation 1:

$$
\mathrm{SR}=\frac{\mathrm{C}_{50} \text { Soil }-\mathrm{C}_{50} \text { Sand }}{\mathrm{C}_{50} \text { Sand }}
$$

\section{Determination of sorption and desorption by the high-performance liquid chromatography method}

The test was performed in triplicate, using a high-performance liquid chromatograph (HPLC), Shimadzu ${ }^{\circledR}$ LC 20AT model, Japan, with UV/vis detector (Schimadzu SPD-20A) and C18 stainless steel column (VP, ShimadzuShim-pack ODS $150 \times 6$ $\mathrm{mm} \times 4 \mathrm{~mm}$ id.). Acetonitrile and water (acidified with $0.01 \%$ acetic acid) were used as mobile phase in the proportion of $60: 40(\mathrm{v}: \mathrm{v})$, with injection volume of $20 \mu \mathrm{L}$, at a flow rate of $1.0 \mathrm{~mL} \mathrm{~min}^{-1}$ and wavelength of $212 \mathrm{~nm}$, at a temperature of $30{ }^{\circ} \mathrm{C}$ (RAMÍREZ et al., 2018), conditions that resulted in a retention time of indaziflam equal to 4.6 minutes.

The equilibrium time of indaziflam sorption in each substrate was determined using the batch equilibrium method, which is highly efficient to describe the sorption of herbicides in soil (ALONSO et al., 2011). This determination was performed by following the methodology proposed by Ramírez et al. (2018): 2 grams of soil is placed in Falcon tubes, followed by the addition of $10 \mathrm{~mL}$ of $0.01 \mathrm{~mol} \mathrm{~L}^{-1}$ $\mathrm{CaCl}_{2}$ solution, containing $1 \mathrm{mg} \mathrm{L}^{-1}$ of the analytical standard of the herbicide indaziflam. Then, the soil + solution mixture is subjected to vertical shaking for different times $(2 ; 4 ; 8 ; 12 ; 24$ and $32 \mathrm{~h})$ at a temperature of $25 \pm 2{ }^{\circ} \mathrm{C}$. Then, the tubes are centrifuged at $3000 \mathrm{rpm}$ for seven minutes and the supernatant solution is removed and filtered in Millipore filter with $0.45-\mu \mathrm{m}$ polytetrafluoroethylene (PTFE) membrane, to obtain $1.5 \mathrm{~mL}$ of impurity-free solution, which is used for reading in HPLC.

In the determination of indaziflam sorption, $10 \mathrm{~mL}$ of working solution, prepared at concentrations of $0.5,1.0,1.5,2.0,2.5$ and $3.0 \mathrm{mg} \mathrm{L}^{-1}$ of the herbicide in $0.01 \mathrm{~mol} \mathrm{~L}^{-1} \mathrm{CaCl}_{2}$ were added to Falcon tubes containing $2 \mathrm{~g}$ of soil, which were subjected to vertical shaking for $12 \mathrm{~h}$ (time determined in both soils as equilibrium time). Then, the tubes were centrifuged at $3000 \mathrm{rpm}$ for seven minutes and $1.5 \mathrm{~mL}$ of the supernatant was filtered in Millipore filter with $0.45-\mu \mathrm{m}$ PTFE membrane, for analysis by HPLC. The amount of indaziflam adsorbed to the soil (Cs) in $\mathrm{mg} \mathrm{kg}^{-1}$ was obtained from the difference between the amount initially added $(C p)$ and the amount found in the equilibrium solution $(C e)$. With the values of $C s$ and $C e$, the Freundlich equation $\left(C s=K f C e^{l / n}\right)$ was fitted to obtain the sorption coefficients $(K f)$ and the linearization factor $(1 / n)$, in which $C_{s}=$ amount of herbicide adsorbed in $\mathrm{mg} \mathrm{g}^{-1}$ of soil; $C_{a q}=$ herbicide concentration in the equilibrium solution in $\mathrm{mg} \mathrm{L}^{-1}$, $K_{f}$ is the Freundlich adsorption coefficient in $\mathrm{L} \mathrm{mg}^{-1}$ and $1 / n=$ linearization factor that determines the sorption intensity (ALONSO et al., 2011).

Indaziflam desorption was additionally performed in the HPLC method immediately after sorption at all points of the isotherms; $10 \mathrm{~mL}$ of $0.01 \mathrm{~mol} \mathrm{~L}^{-1} \mathrm{CaCl}_{2}$ solution, free of herbicide, were added to the tubes that contained soil after the sorption test. These tubes were subjected to new shaking, under the same conditions used for the sorption test. They were then centrifuged for seven minutes at 3,000 rpm to obtain the supernatant, which was collected and filtered in a Millipore filter with $0.45-\mu \mathrm{m}$ PTFE membrane to obtain $1.5 \mathrm{~mL}$ of filtrate, used in HPLC analysis. The hysteresis index was calculated by dividing the $(1 / \mathrm{n})$ index of the sorption by the $(1 / \mathrm{n})$ index of the desorption (PERUCHI; FOSTIER; RATH, 2015).

The calculation of the amount of desorbed indaziflam took into account the herbicide concentration in the soil before the desorption stage and the concentration in the solution analyzed after extraction. The amount of herbicide still adsorbed to the soils at each desorption stage was calculated as the difference between the adsorbed amount and the desorbed amount of the herbicide.

Quantification was performed by comparing the areas obtained in the chromatograms after the tests, and the identification, based on the retention time, was made by comparison with the analytical standard of indaziflam. The data obtained were subjected to regression analysis in $\mathrm{R}$ software, considering the fitting of the values observed in the dependent variable $(\mathrm{Y})$ as a function of the variation of the levels of the independent variable $(\mathrm{X})$. The graphics were generated in SigmaPlot software v. 14.0.

\section{RESULTS AND DISCUSSION}

\section{Bioassay}

The dose-response curves for percentage of intoxication and total dry matter accumulation of $S$. bicolor cultivated in the inert substrate, at 21 days after the application of indaziflam doses, are presented in Figures $1 \mathrm{~A}$ and 1B, respectively. 

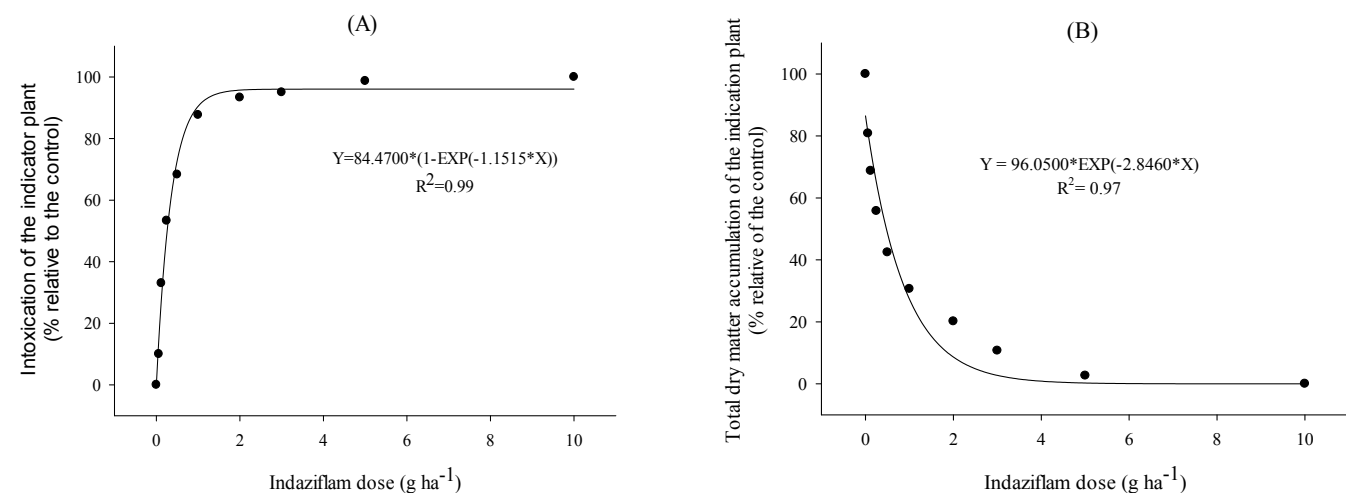

Figure 1. Dose-response curve of the herbicide indaziflam, percentage of intoxication (A) and total dry matter accumulation (B) of $S$. bicolor plants, cultivated in inert substrate in evaluation performed at 21 days after indaziflam application.

The curves shown in Figure 1 were used to calculate the values of the $C_{50}$ dose, equal to $0.39 \mathrm{~g} \mathrm{ha}^{-1}$ for intoxication and to $0.23 \mathrm{~g} \mathrm{ha}^{-1}$ for total dry matter accumulation of the plants, cultivated in inert substrate. As it is an inert substrate, all herbicide applied is considered to be available in the solution, because its specific physical and chemical characteristics such as absence of organic matter and clay and absence of surface charges make the sorption of the products unfeasible. This makes them available for absorption by plant roots, which reduces the applied doses in this substrate (INOUE et al., 2003; SOUZA, 2018).

(A)

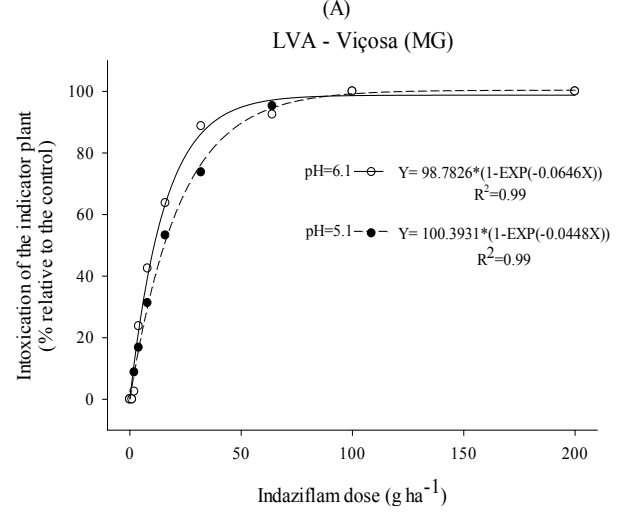

(C)

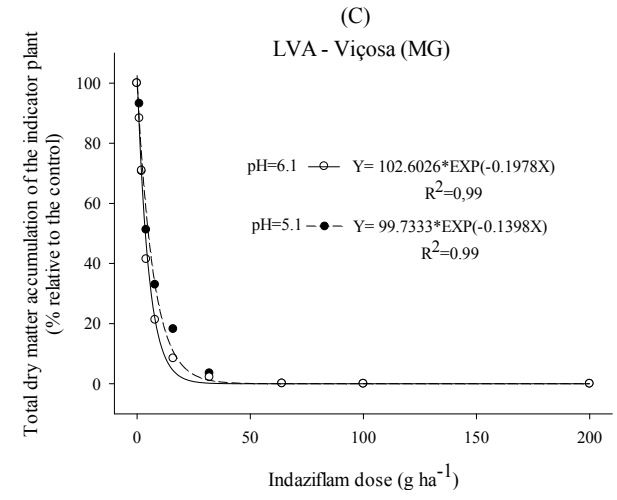

In the soils (LVA and CX), the increase of $\mathrm{pH}$ from 5.1 to 6.1 caused increments in the percentage of intoxication (Figures $2 \mathrm{~A}$ and $2 \mathrm{~B}$ ) and reduction in the total dry matter accumulation (Figures $2 \mathrm{C}$ and 2D) of $S$. bicolor plants, after indaziflam application, mainly at doses between 4 and $64 \mathrm{~g} \mathrm{ha}^{-1}$. These results show that, in these soils, the increase of $\mathrm{pH}$ alters the sorption behavior of indaziflam. According to Alonso et al. (2011), with the increase in soil $\mathrm{pH}$, herbicides derived from weak acids such as indaziflam, become more available in the soil solution, subject to being more absorbed by plants or carried to greater depths.

(B)

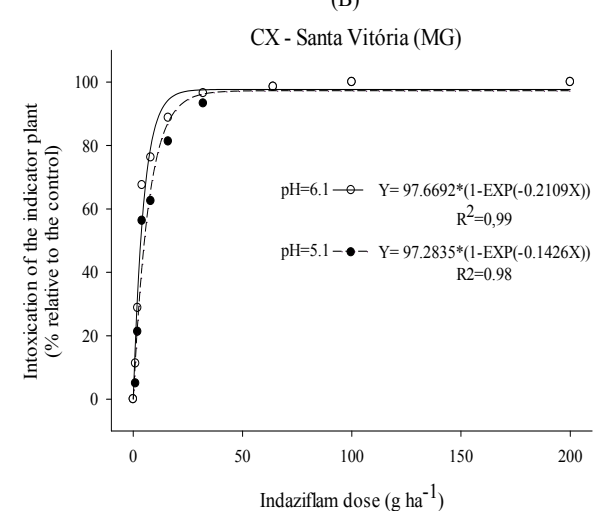

(D)

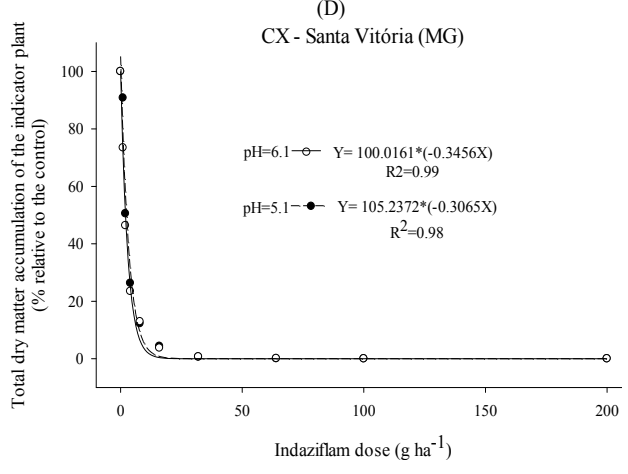

Figure 2. Percentage of intoxication of S. bicolor plants grown in Latossolo Vermelho-Amarelo (LVA) (A) and Cambissolo (CX) (B) and total dry matter accumulation of the plants in these same soils (LVA (C) and CX (D)), at two pH values (5.1 and 6.1), in evaluations performed at 21 days after indaziflam application. 
A study with the herbicides imazethapyr and imazapyr, which have low $\mathrm{pKa}$ value like indaziflam, found that the $\mathrm{pH}$ value of the soil solution is the main responsible for determining the form of the herbicide (molecular or dissociated) (REFATTI et al., 2014). Thus, for these herbicides, when the $\mathrm{pH}$ value of the soil solution is close to neutrality and/or higher than the $\mathrm{pKa}$ value of the herbicide, there will be predominance of the dissociated form (ionic form). This form will be repelled by the negative charges present in abundance in soil surface, reducing sorption and making the product more available in the soil solution (REFATTI et al., 2014). This fact would contribute to a greater absorption of indaziflam by $S$. bicolor plants. This explains the increase in the percentage of intoxication and consequent reduction in the dry matter accumulation of the species that were cultivated in the soil with increased $\mathrm{pH}$.

Cáceres et al. (2010) evaluated the sorption of metsulfuron-methyl, an herbicide with characteristics similar to those of indaziflam, classified in the chemical group of weak acids with low $\mathrm{pKa}$ value (3.3). The authors observed that the increase in soil solution $\mathrm{pH}$ up to 6.1 led to a significant reduction in sorption, confirming the influence of this soil characteristic on the sorption behavior of the herbicide.

The $C_{50}$ values of the variables percentage of intoxication and dry matter accumulation of $S$. bicolor, in both LVA and CX, were higher than that of the inert substrate (Table 2). However, when analyzing the $C_{50}$ values and the sorption rate of the two soils, not considering the inert substrate, it is possible to observe that the values obtained in LVA (15.39 $\mathrm{pH} 5.1$ and $10.92 \mathrm{pH} \mathrm{6.1)}$ are higher than those found in $\mathrm{CX}(5.04 \mathrm{pH} 5.1$ and $3.40 \mathrm{pH} 6.1)$. It can be said in this case that the difference is due to the distinct characteristics that the LVA has, especially higher contents of organic matter and clay (Table 1).

It is known that the humic fraction of the organic matter components of a soil is adsorbed in greater amounts than the total organic matter (SOUZA, 2018), although it is not an herbicide derived from a weak base. Higher $\mathrm{Kf}$ values of 2,4-D were observed in the presence of organic matter compared to the absence of organic matter in a soil (VIEIRA et al., 1999). On the other hand, despite being composed mostly of non-expandable clays $(1: 1)$, soils with this component can adsorb herbicides. The charges are generated at the edges of minerals through the dissociation of $\mathrm{H}^{+}$and $\mathrm{OH}^{-}$ groups. Iron and aluminum oxides also act on the sorption of several herbicides, especially those with molecular dissociation capacity (SILVA; VIVIAN; OLIVEIRA JR., 2013).

Table 2. Indaziflam dose causing 50\% intoxication and 50\% reduction in the total dry matter accumulation of S. bicolor plants $\left(\mathrm{C}_{50}\right)$ and herbicide sorption rate $(\mathrm{SR})$, in evaluations performed at 21 days after application.

\begin{tabular}{|c|c|c|c|c|}
\hline \multirow{2}{*}{ Substrate } & \multicolumn{2}{|c|}{ Intoxication } & \multicolumn{2}{|c|}{ Total dry matter } \\
\hline & $\mathrm{C}_{50}\left(\mathrm{~g} \mathrm{ha}^{-1}\right)$ & SR & $\mathrm{C}_{50}\left(\mathrm{~g} \mathrm{ha}^{-1}\right)$ & SR \\
\hline Inert substrate & 0.39 & - & 0.23 & - \\
\hline $\mathrm{LVA}-\mathrm{pH}=5.1$ & 15.39 & 38.46 & 4.93 & 20.43 \\
\hline $\mathrm{LVA}-\mathrm{pH}=6.1$ & 10.92 & 27.00 & 3.82 & 15.61 \\
\hline $\mathrm{CX}-\mathrm{pH}=5.1$ & 5.04 & 11.92 & 2.42 & 9.52 \\
\hline $\mathrm{CX}-\mathrm{pH}=6.1$ & 3.40 & 7.71 & 2.01 & 7.74 \\
\hline
\end{tabular}

The specific physical and chemical characteristics of each soil allow different herbicide sorption capacities, especially mineralogy and organic matter content (GREY et al., 2016; JEFFRIES; GANON, 2016). These are attributes that are directly involved in the process of sorption of molecules, because they have three-dimensional sites that form hydrogen bonds with herbicides, which are responsible for the sorption of ionic and non-ionic herbicides (SILVA; VIVIAN; OLIVEIRA JR., 2013; INOUE et al., 2014). In addition, the prolonged permanence of the herbicide in the soil solution, influenced by lower sorption, may have direct consequences on mobility, degradation, persistence and risk of contamination of surface water and groundwater. Irreversible damage to soil macro and microfauna may also occur and directly affect agronomic efficiency in weed control.

\section{Test using high-performance liquid chromatography (HPLC)}

The sorption kinetic curves showed different behaviors in each soil (Figure 3). The highest indices were observed in both soils at $\mathrm{pH}=5.1$. Aiming at greater safety regarding the equilibrium time and greater ease during the test, it was decided to work with the time of $12 \mathrm{~h}$, the same for both soils. During the initial phase of equilibrium time determination, there was a rapid sorption followed by a slow phase. 
This is due to the large number of sorption sites available in the soil during the initial phase, which are occupied over time, reducing the sorption rate (LIU et al., 2010).
Freundlich isotherms adequately represented the sorption of this herbicide in both LVA and CX, which can be noted by the coefficients of determination $\left(\mathrm{R}^{2}\right)$, equal to 0.99 (Figure 4$)$.

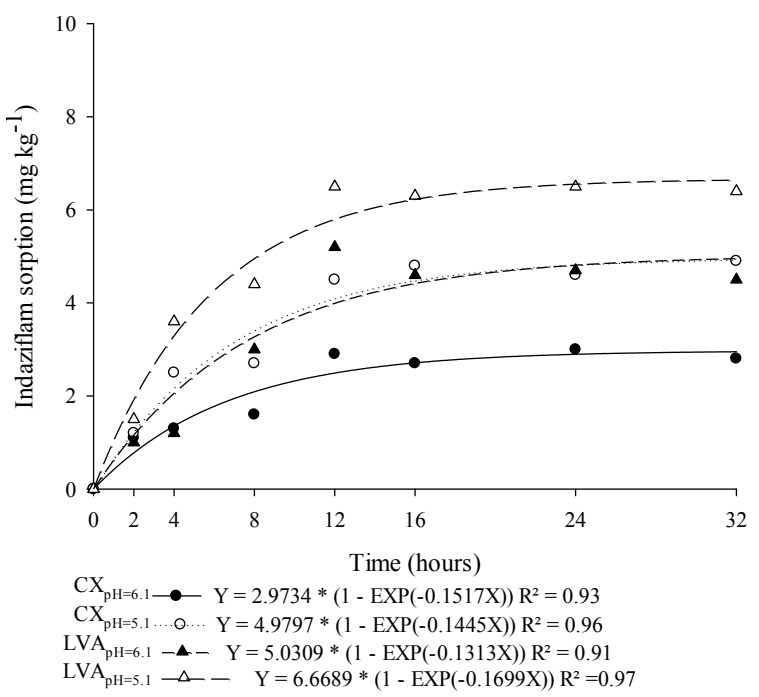

Figure 3. Estimates of indaziflam sorption kinetic curves in two soils: Cambissolo (CX) and Latossolo Vermelho-Amarelo (LVA), at two $\mathrm{pH}$ values (5.1 and 6.1) and evaluated over time.

(A)

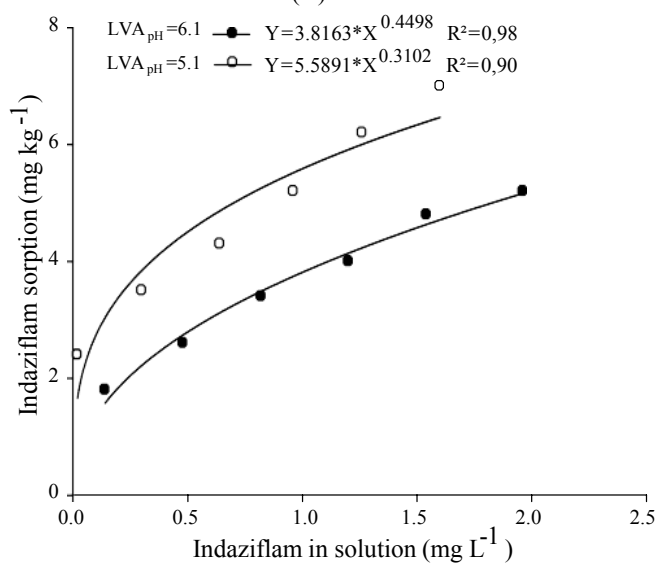

(B)

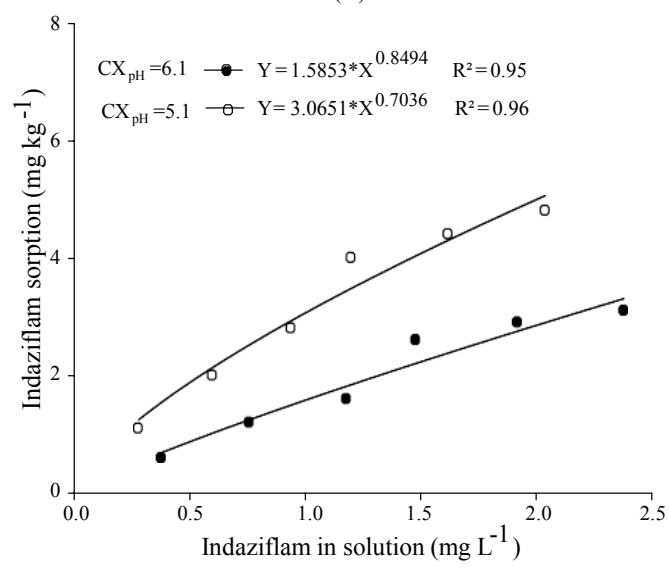

Figure 4. Indaziflam sorption in Latossolo Vermelho-Amarelo (LVA) (A) and Cambissolo (CX) (B) with different $\mathrm{pH}$ values.

The parameter $1 / \mathrm{n}$, a factor that determines the linearization and intensity of herbicide sorption (SILVA; VIVIAN; OLIVEIRA JR., 2013), ranged from 0.3102 to 0.8494 (Figure 4). In this case, Ltype isotherms can be fitted, because the values are lower than 1.0. L-type isotherms show nonlinear and concave inclination in relation to the $\mathrm{X}$-axis, suggesting that the availability of sites for indaziflam sorption decreases as a result of saturation of the sorption sites in the soil (SILVA et al., 2012).

The analysis of the $1 / n$ parameter of the
Freundlich equation made it possible to estimate the interaction of ions in solution with the solvent; in this case, when $n>1$, the curve of the model will have a concave shape, indicating favorable condition to sorption; when $\mathrm{n}=1$, the linear form will be observed, in this case the energy sites will be equivalent, maintaining the equilibrium condition and, when $\mathrm{n}<1$, the isotherm will have a convex shape in relation to the $\mathrm{X}$-axis, characterizing an unfavorable condition to sorption (HARO et al., 2013). In this study, an unfavorable condition to sorption was 
observed, especially in the conditions in which the soils have higher $\mathrm{pH}$ value, since there is rapid saturation of the available sites.

Kf values (sorption) ranged from 3.0651 to 5.5891 (Figure 4 and Table 3), being lower in $\mathrm{CX} \mathrm{pH}=6.1$ and higher in $\mathrm{LVA} \mathrm{pH}=5.1$, which are low according to the classification of IBAMA (1990). Based on this result, indaziflam can be characterized as a herbicide of low sorption in the two soils studied and, therefore, available for absorption by plants.

Table 3. Freundlich equation parameters of indaziflam sorption and desorption in Latossolo Vermelho-Amarelo (LVA) and Cambissolo $(\mathrm{CX})$ with different $\mathrm{pH}$ values.

\begin{tabular}{ccccc}
\hline Sorption coefficients & \multicolumn{2}{c}{ LVA } & CX \\
\cline { 2 - 5 }$K f$ & $\mathrm{pH} \mathrm{5.1}$ & $\mathrm{pH} \mathrm{6.1}$ & $\mathrm{pH} \mathrm{5.1}$ & $\mathrm{pH} \mathrm{6.1}$ \\
$1 / n$ & 3.1296 & 2.2927 & 2.4698 & 1.4733 \\
$\mathrm{R}^{2}$ & 0.7239 & 0.7652 & 0.8388 & 0.9586 \\
& 0.90 & 0.98 & 0.95 & 0.96 \\
Desorption coefficients & & & \\
$K f$ & 1.2655 & 1.3118 & 2.4273 & 1.3835 \\
$l / n$ & 0.7611 & 0.9056 & 0.5810 & 1.0298 \\
$\mathrm{R}^{2}$ & 0.99 & 0.98 & 0.89 & 0.79 \\
\hline$H$ & 0.9511 & 0.8449 & 1.4437 & 0.9309 \\
\hline
\end{tabular}

$K f$ - Freundlich sorption coefficient; $1 / n$ - Linearization factor; $\mathrm{R}^{2}$ - coefficient of determination of the equation, and hysteresis index $(\mathrm{H})$.

Understanding the strength with which herbicides are adsorbed to soils is extremely important, as this will determine how much of the herbicide will be retained in the soil and how much will be available in the solution with the possibility of being absorbed by plants, undergoing microbial degradation, photolysis, leaching and transport to deeper layers (Run In) or by runoff (SILVA; VIVIAN; OLIVEIRA JR., 2013).

The desorption of indaziflam was inversely related to the sorption coefficient $(K f)$ because the lowest desorption values were observed under the conditions of highest $K f s$, especially in LVA (Figure 5 ). This means that in the condition of lower value of soil $\mathrm{pH}$, indaziflam will have lower desorption capacity, which according to Souza. (2018) is the result of strong bonds between herbicide and soil, hindering the desorption process. Herbicides with low desorption rate may pose higher risk for sensitive crops in succession, as they are released slowly, increasing the persistence in soil (SCURSONI et al., 2017).
(A)

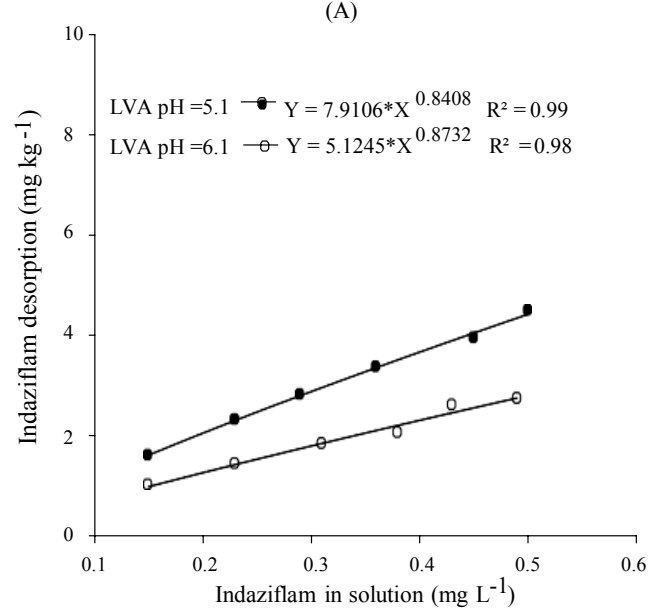

(B)

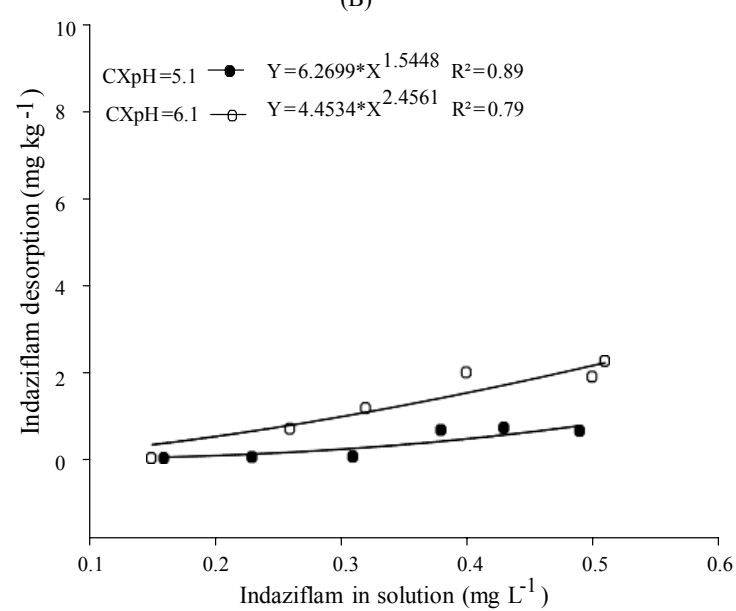

Figure 5. Desorption of indaziflam in Latossolo Vermelho-Amarelo (LVA) (A) and Cambissolo (CX) (B), with different $\mathrm{pH}$ values. 
The importance of desorption is related to the release rate and the mobility potential of herbicides in the soil, indicating the degree of reversibility of the sorption process. This can be total, when all adsorbed herbicide returns to the soil solution, or partial, when only part of the adsorbed herbicide returns to the soil solution (ALONSO et al., 2011).

The permanence of the adsorbed herbicide originates the phenomenon called hysteresis $(\mathrm{H})$, which is characterized by the almost irreversible sorption of the herbicide to soil solution (SILVA et al., 2012). It is observed that, for the studied soils, the increase in $\mathrm{pH}$ value reduces the hysteresis indices (Table 3). This means that, in these soils, the amount of herbicide that tends to return to the soil solution increases with the increase in $\mathrm{pH}$, that is, this herbicide will be more easily available again to plants (MELO et al., 2010; ALONSO et al., 2011; SILVA et al., 2013b).

The fact that there is greater desorption of indaziflam after the increase in $\mathrm{pH}$ may pose a higher risk for crops in succession, since the practice of liming, an operation often performed before planting the crops, will contribute to the release of the herbicide that was adsorbed, making it available in the soil solution, which may cause damage to sensitive crops, a phenomenon called carryover (LIU et al., 2010).

In both methods of sorption determination (bioassay and high-performance liquid chromatography), it was found that the increase in $\mathrm{pH}$ of the solution of the studied soils caused reduction in indaziflam sorption. This confirms that the bioassay method can be successfully used when it comes to the study of indaziflam sorption, despite being a method of great simplicity and limitation. However, it is important to emphasize that, in order to obtain clearer and more objective results, both methods should be used, as the sensitivity of detection of the bioassay will be combined with the quantification capacity of chromatography.

\section{CONCLUSIONS}

In LVA, indaziflam sorption decreases more markedly with the increase in $\mathrm{pH}$, while desorption increases.

Safe recommendations of indaziflam from both the agronomic and the environmental points of view in Latossolo Vermelho-Amarelo and Cambissolo are mainly influenced by the $\mathrm{pH}$ value.

Bioassay and high-performance liquid chromatography techniques are efficient in determining indaziflam sorption in the studied soils.

\section{REFERENCES}

ALONSO, D. G. et al. Sorption - desorption of indaziflam in selected agricultural soils. Journal of Agricultural and Food Chemistry, 59: 1309613101, 2011.

ALONSO, D. G. et al. Changes in sorption of indaziflam and three transformation products in soil with aging. Geoderma, 239: 250-256, 2015.

ALONSO, D. G. et al. Sorption and desorption of indaziflam degradates in several agricultural soils. Scientia Agricola, 73: 169-176, 2016.

BRABHAM, C. et al. Indaziflam herbicidal action: a potent cellulose biosynthesis inhibitor. Plant Physiology, 166: 1177-1185, 2014

BARCELLOS JÚNIOR, L. H. et al. Influence of Organic Matter in Sorption of the Saflufenacil in Ferralsols. Bulletin of Environmental Contamination and Toxicology, s/v: 1-6, 2020.

BRAGA, R. R. Sorção de indaziflam e isoxaflutole em solos tropicais. 2017. 45 p. Tese (Doutorado em Fitotecnia: Área de concentração em produção vegetal). Universidade Federal de Viçosa, Viçosa, 2017.

BRAGA, R. R. et al. Selection of vegetable indicators of indaziflam residues in soil. Revista Brasileira de Ciências Agrárias, 15: e7737, 2020.

BROSNAN, J. T. et al. Pre and Post control of annual bluegrass (Poa annua) with indaziflam. Weed Technology, 26: 48-53, 2012.

CÁCERES, L. et al. Metsulfuron-methyl sorption/ desorption behavior on volcanic ash-derived soils. Effect of phosphate and pH. J. Agric. Food Chemistry, 58: 6864-6869, 2010.

CALDERON, M. J. et al. Herbicide monitoring in soil, runoff waters and sediments in an olive orchard. Science of the Total Environment, 569: 416-422, 2016

CARLES, L.; JOLY, M.; JOLY, P. Mesotrione herbicide: efficiency, effects and fate in the environment after 15 years of agricultural use. CLEAN-Soil, Air, Water, 45: 1-8, 2017.

FAOSTAT - Food and Agriculture Organization of the United Nations. Pesticides Use. Disponível em: $<$ http://www.fao.org/faostat/en/\#data/RP $>$. Acesso em: 20 jan. 2021

GREY, T. L. et al. High-Density plantings of olive trees are tolerant to repeated applications of indaziflam. Weed Science, 64: 766-771, 2016. 
GUERRA, N. et al. Aminocyclopyrachlor e indaziflam: Seletividade, controle e comportamento no ambiente. Revista Brasileira de Herbicidas, 12: 285-295, 2013.

HARO, N. K. et al. Remoção de bisfenol-a por adsorção. 2013，119p. Dissertação (Mestrado em Engenharia Química: Área de Fenômenos de Transporte e Operações Unitárias) - Universidade Federal do Rio Grande do Sul, Porto Alegre, 2013.

IBAMA - Instituto Brasileiro do Meio Ambiente e dos Recursos Naturais Renováveis. Manual de testes para avaliação da ecotoxicidade de agentes químicos. Teste para avaliação da mobilidade, Brasília, DF: IBAMA, 1990. 230 p.

INOUE, M. H. et al. Critérios para avaliação do potencial de lixiviação de herbicidas comercializados no estado do Paraná. Planta Daninha, 21: 313-323, 2003.

INOUE, M. H. et al. Potencial de lixiviação de imazapic e isoxaflutole em colunas de solo. Planta Daninha, 25: 547-555, 2007.

INOUE, M.H. et al. Potencial de lixiviação de herbicidas utilizados na cana-de-açúcar em solos contrastantes. Bioscience Journal, 30: 659-665, 2014.

JEFFRIES M. D.; GANNON, T. W. Soil Organic Matter Content and Volumetric Water Content Affect Indaziflam-Soil Bioavailability. Weed Science, 64: 757-765, 2016.

JHALA, A. J.; RAMIREZ, A. H. M.; SINGH, M. Leaching of indaziflam applied at two rates under different rainfall situations in Florida dandler soil.

Bulletin of Environmental Contamination and Toxicology, 88: 326-332, 2012.

KAAPRO, J.; HALL, J. Indaziflam, a new herbicide for pre-emergent control of weeds in turf, forestry, industrial vegetation and ornamentals. Pakistan Journal Weed Science Research, 18: 267-270, 2012.

KHAN, M. A., BROWN, C. D. Influence of commercial formulation on the sorption and leaching behaviour of propyzamide in soil. Science of the Total Environment, 578: 158-166, 2017.

LIU, Y. et al. Adsorption and desorption behavior of herbicide diuron on various Chinese cultivated soils. Journal Hazardous Materials, 178: 462-468, 2010.

MELO, C. A. D. et al. Lixiviação de sulfentrazone, isoxaflutole e oxyfluorfen no perfil de três solos.
Planta Daninha, 28: 385-392, 2010.

PERUCHI, L. M., FOSTIER, A. H., RATH, S. Sorption of norfloxacin in soils: analytical method, kinetics and Freundlich isotherms. Chemosphere, 119: 310-317, 2015.

REFATTI, J. P. et al. Efeito da calagem na lixiviação de imazethapyr e imazapyr em solo de cultivo de arroz irrigado. Ciência Rural, 44: 1008-1014, 2014.

RAMÍREZ, A. C. R. et al. Development and validation of a solid-liquid extraction with low temperature partitioning (SLE/LTP) method for determination of the herbicide indaziflam in brazilian soils by high performance liquid chromatography (HPLC-UV/Vis). Journal of Experimental Agriculture International, 21: 1-8, 2018.

SBCPD - SOCIEDADE BRASILEIRA DA CIÊNCIA DAS PLANTAS DANINHAS. Procedimentos para instalação, avaliação e análise de experimentos com herbicidas. Londrina, PR: S.B.C.P.D., 42 p. 1995.

SCURSONI, J. A. et al. Impact of Imazamox and Imazapyr Carryover on Wheat, Barley, and Oat. Weed Technology, 31: 838-846, 2017.

SILVA, L. O. C. et al. Mobilidade do ametryn em Latossolos brasileiros. Planta Daninha, 30: 883$890,2012$.

SILVA, A. A. et al. Métodos de controle de plantas daninhas. In: SILVA, A. A.; SILVA, J. F. (Eds.). Tópicos em manejo de plantas daninhas. Viçosa, MG: Universidade Federal de Viçosa, 2013a. cap. 2, p. 63-81

SILVA, A. A.; VIVIAN, R.; OLIVEIRA JR., R. S. Herbicidas: Comportamento no solo. In: SILVA, A. A.; SILVA, J. F. (Eds.). Tópicos em manejo de plantas daninhas. Viçosa, MG: Universidade Federal de Viçosa, 2013b. cap. 3, p. 189-248.

SILVA, G. R. et al. Sorption of fomesafen in Brazilian soils. Planta Daninha, 31: 971-977, $2013 b$.

SOUZA, W. M. Influência dos atributos do solo na sorção e lixiviação do indaziflam em solos tropicais. 2018. 76 f. Dissertação (Mestrado em Fitotecnia: Área de Concentração Produção Vegetal) - Universidade Federal de Viçosa, Viçosa, 2018.

VIEIRA, E. M. et al. Estudo da adsorção/dessorção do ácido 2,4 diclorofenoxiacético $(2,4 \mathrm{D}) \mathrm{em}$ solo na ausência e presença de matéria orgânica. Química Nova, 22: 305-308, 1999 
U. S. EPA. Pesticide fact sheet. Registration sheet of indaziflam. 2010, 108 p. Disponível em <https:// www3.epa.gov/pesticides/chem_search/reg_actions/ registration/fs_PC-080818_26-Jul-10.pdf> Acesso em: 29 mar. $20 \overline{2} 1$. 